\title{
Effectiveness of meta-cognitive therapy on alcoholism potential in students
}

\author{
Hossein Farrokhi $^{1 *}$ (D), Faramarz Sohrabi ${ }^{2}$, Ali Delavar ${ }^{3}$ \\ 1. Master Student of Clinical Psychology, Faculty of Psychology and Education, University of Allameh Tabataba'i, Tehran, Iran \\ 2. Professor of Clinical Psychology, Faculty of Psychology and Education, University of Allameh Tabataba'i, Tehran, Iran \\ 3. Professor of Statistics and Research Method, Faculty of Psychology and Education, University of Allameh Tabataba'i, Tehran, Iran
}

Recieved: 7 Oct. 2017

Revised: 11 Jul. 2018

Accepted: 28 Aug. 2018

Keywords

Metacognitive therapy

Alcoholism potential

Students

\section{Corresponding author}

Hossein Farrokhi, Master Student of Clinical Psychology, Faculty of Psychology and Education, University of Allameh Tabataba'i, Tehran, Iran

Email: Hossein.farrokhi110@yahoo.com

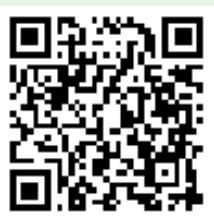

doi.org/10.30699/icss.21.2.32

\section{Abstract}

Introduction: Alcohol addiction is an important phenomenon, which has attracted college students because of its multi-variable nature. This study aimed to determine the effectiveness of meta-cognitive group therapy on the alcoholism potential in male students. Methods: This study was considered as a semi-experimental research which has used the pretest-post-test with control group and follow-up stage design. The statistical population included all of the undergraduate male students at Ferdowsi University of Mashhad in the academic year 2017. The sample including 30 subjects was selected by the cluster sampling and they were assigned into experimental and control groups. In this study, meta-cognition questionnaire (MCQ-30) and the addiction potential scale (APS) were used. Results: The obtained data were analyzed using the analysis of covariance and dependent t-test. The covariance and post-test alcoholism potential scores showed that the effect of meta-cognitive therapy on the alcoholism potential of male students was significant $(\mathrm{P}<0.01)$.

Conclusion: Overall, the results indicated that meta-cognitive therapy has decreased the alcoholism potential of the male students and the effect of meta-cognitive therapy on alcoholism potential in a three-month follow-up stage is persistent. 


\title{
اثربخشى فراشناخت درمانى بر ميزان استعداد الكليسم دانشجويان
}

\author{
حسين فرخى" (D) فرامرز سهرابى"، على دلاور"

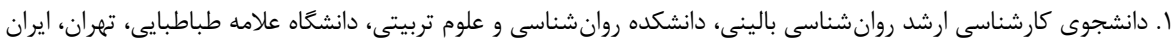

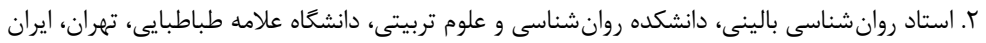

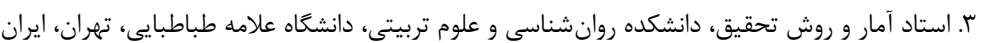

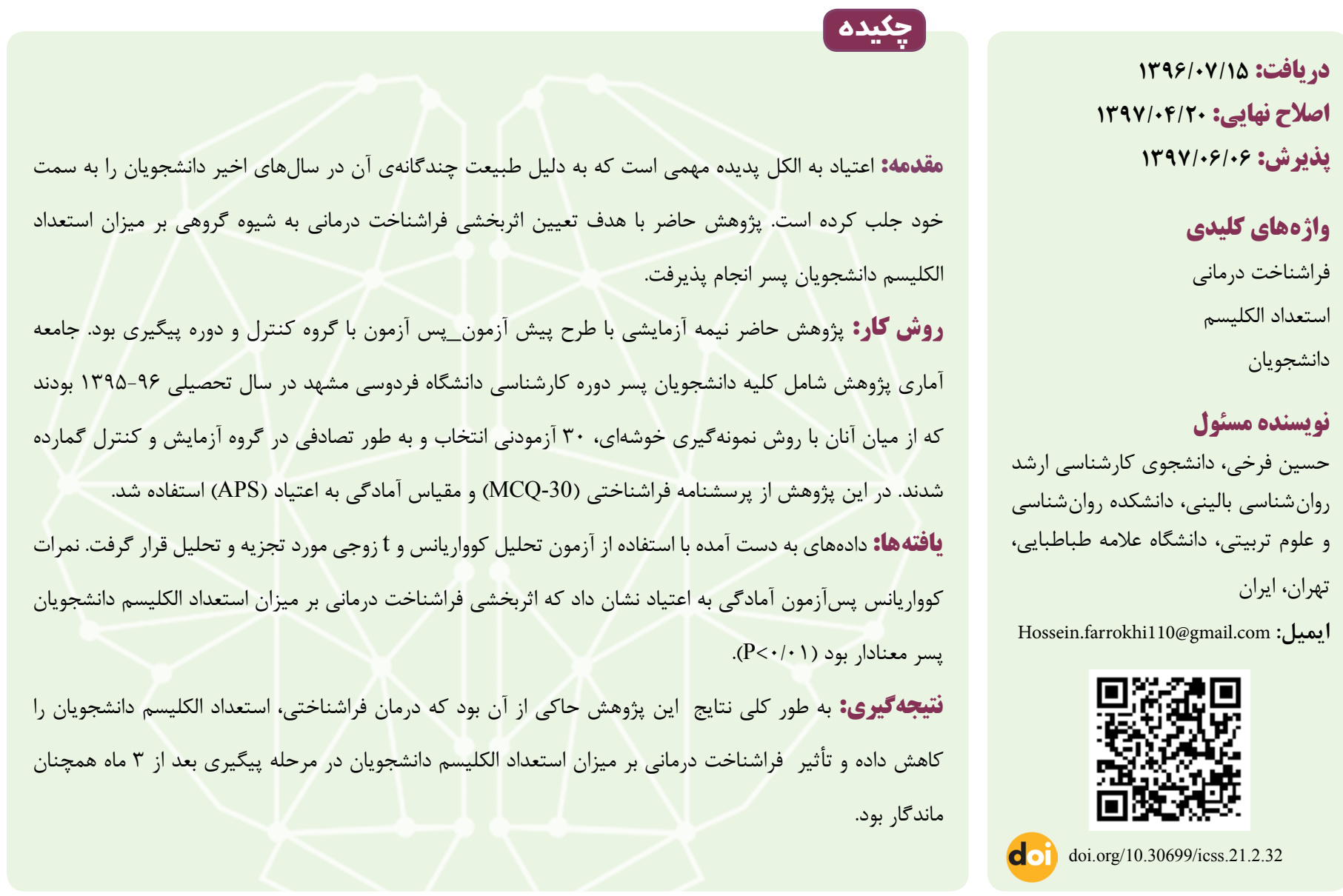

مقدمه

امروزه اعتياد يك بيمارى زيستى_روانى_اجتماعى_معنوى قلمداد از معضلات جهان امروز بوده است (1). يافتههاى جديد بالينى نشان مىشود و عوامل متعددى در گرايش به سوءمصرف مواد مخدر مؤثر مى مدهد كه در شكل گيرى اعتياد به الكل، زمينههاى رشدى ناسالم، استعداد و آمادكى براى اعتياد، نقش اساسى ايفا مىكند. نظريهى است. اختلالات اعتيادى و مصرف مواد، در جايكاه دومين اختلالات استعداد به الكل بيان مى كند برخى از افراد مستعد اعتياد هستند و روانيزشكى بعد از اختلال افسردىى اساسى قرار گرفته است كه از نظر

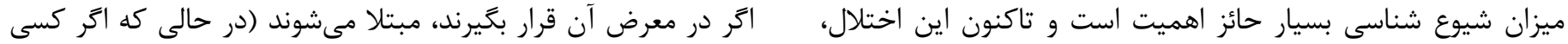


يرداخته مىشود. نتايج مطالعات اخير Wells و همكارانش اين است كه بين باورهاى فراشناختى و وابستكى به مواد رابطه وجود دارد. همجنين

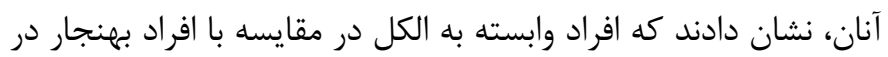

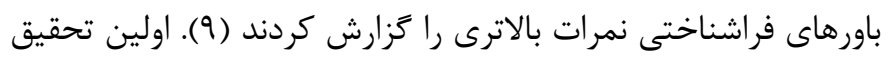

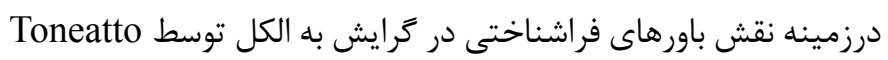

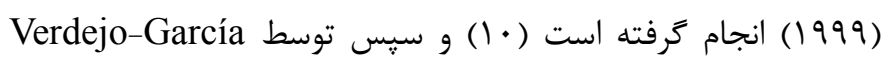

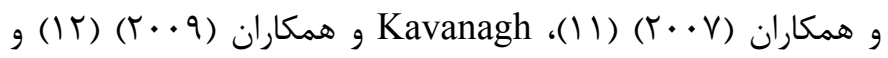

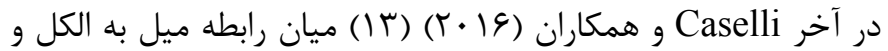
فراشناخت يزوهشهايى صورت گرفته است.

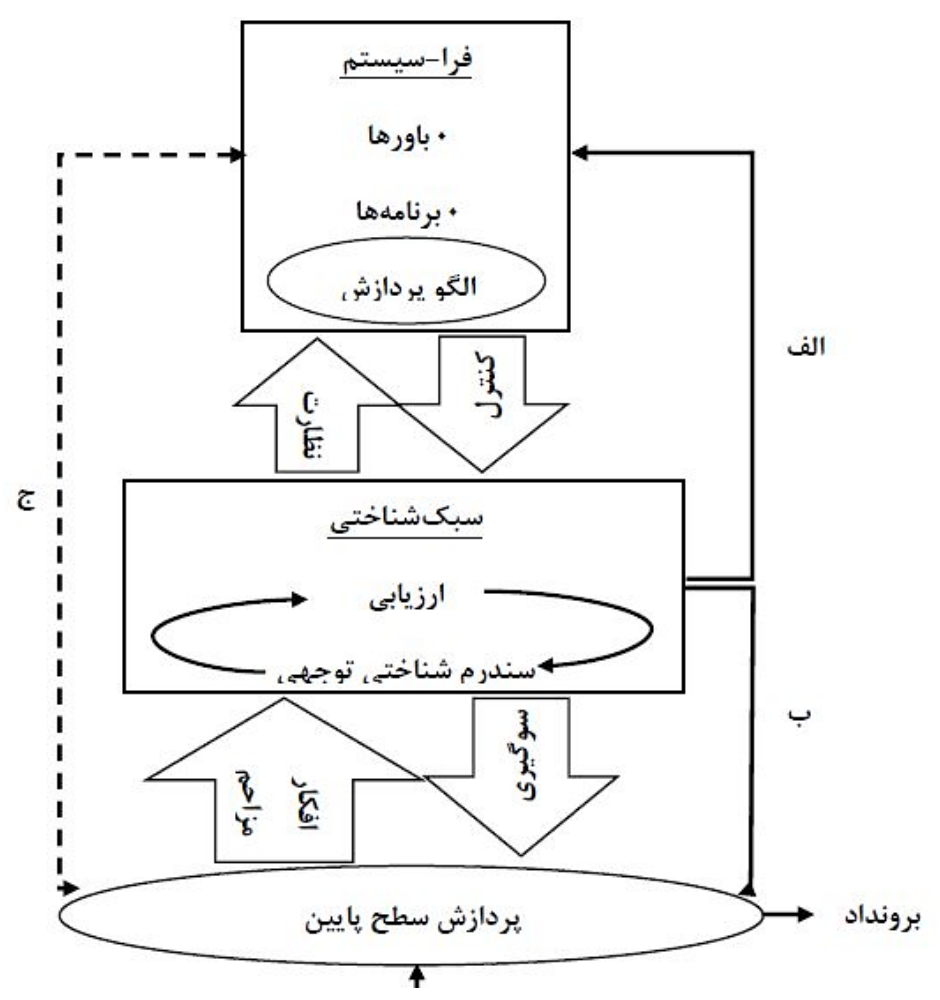

شكل ا. مدل فراشناختى الكليسم

در نتيجه يزوهش حاضر به دنبال شناسايى رفتارهاى مربوط به كرايش

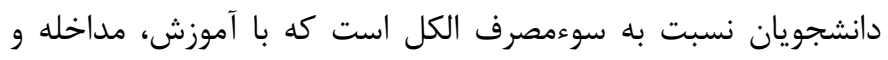

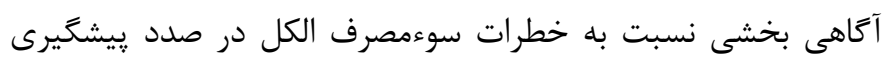
از كرايش به سوءمصرف الكل است. بنابراين، تحقيق حاضر به دنب دنبال

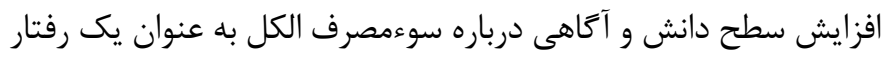

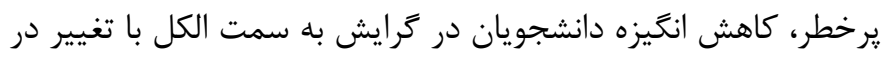
جنبههاى شناختى و فراشناختى نكرش آنان، در جهت ارتقاى بهداشت

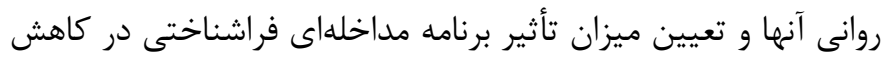

استعداد نداشته باشد، معتاد نمىشود) بر اساس اطلاعات موجود ه

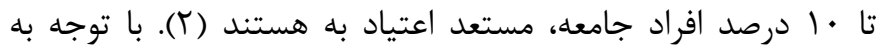

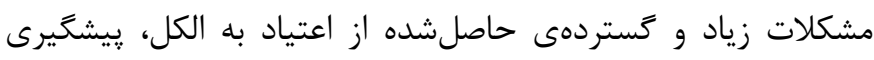

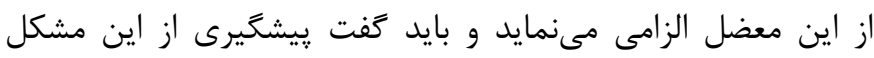

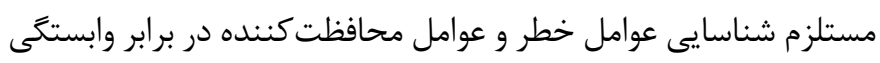

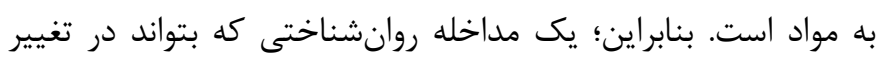

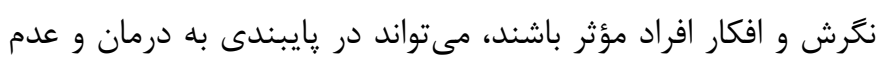

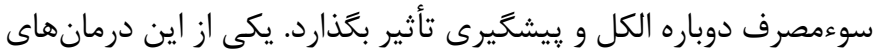
روانشناختى كه امروزه تحقيقات بسيارى را متوجه خود كرده است،

فراشناخت درمانى است كه از سوى Wells مطرح كرديد (r). فراشناخت اطلاعاتى است كه فرد در مورد شناخت، حالات درونى خود التان

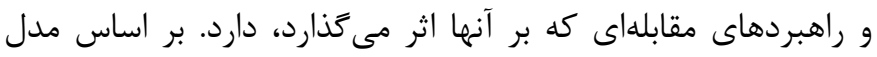

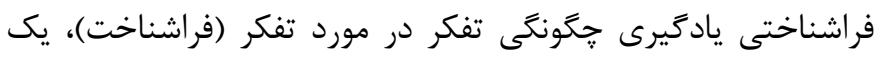

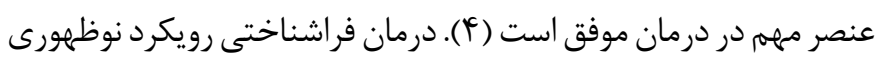

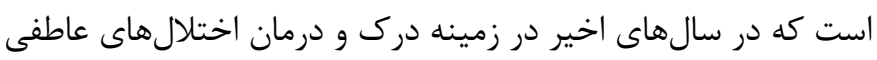

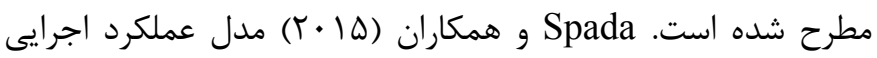
خود نظمبخشى Self-Regulatory Executive Function S-REF را براى اختلال الكليسم ارائه مىدهند (شكل (). اين مدل تعاملات جندكانه شناخت شامل باورها، فراشناختها، كنترل توجه، يردازش إنال ييوسته و خودتنظيمى را بيان مى كند (ه). طى اين سالها جندين

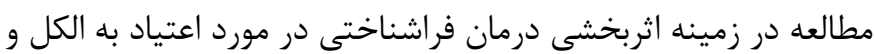

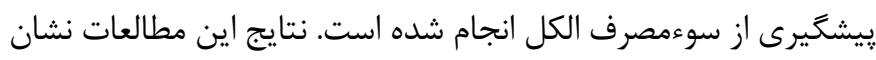

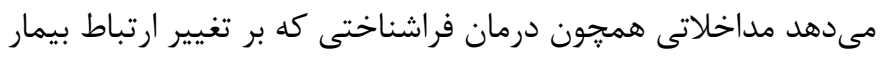

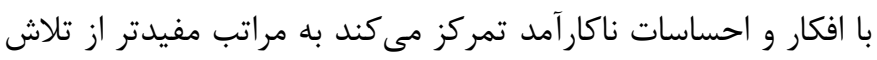

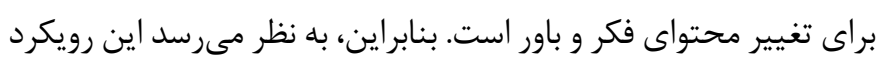

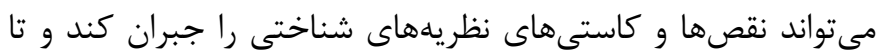

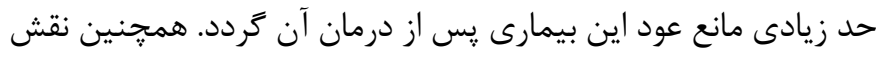
بسزايى در اقدامات بيشخيرانه داشته باشد (و، V). با اين حال، در زمينه

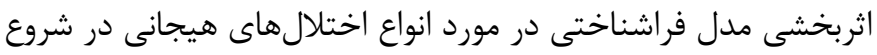
راه هستيم و به جز جند مطالعه كنترل شده، مطالعات زيادى انجام

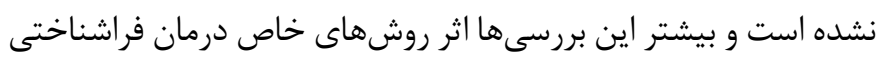

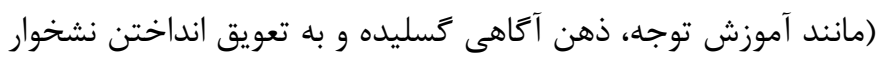

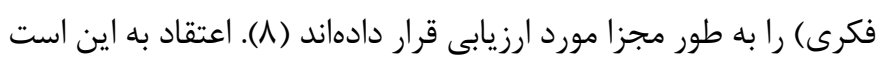

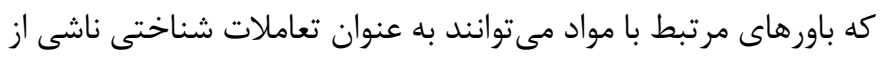
باورهاى فراشناختى و مصرف الكل به عنوان يكى رفتار مقابلهاى ناساز كار باشد. در درمان فراشناخت با روشهايى به اصلاح باورهاى فراشناخت

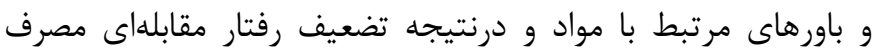


يرسشنامه بر اساس كليد نمرهگذارى مىشود.يرسشنامه از سه خرده مقياس آمادگى اعتياد (APS)، تجربه مواد (Addiction) Acknowledgment Scale و مقياس تجديد نظر شده وابستخى تشكيل (MAC.R) (استعداد به الكليسم) Mac Andrew دارو (MA) شده است. اين سه خرده مقياس مجموعاً مقياس پتانسيل به اعتياد نيز ناميده مىشود. اين : يرسشنامه در سال IPV (APS) كرد ميرزا بر روى دانشجويان دانشعاه تهران هنجاريابى شده است،

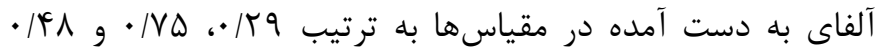
بود (f lf). در اين مطالعه آلفاى به دست آمده توسط يزوهشخً به

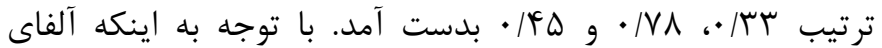
كرونباخ خرده مقياس هاى آزمون يايين مى باشد ولى به دليلى اينكه به غير از اين يرسشنامه، مقياس ديخرى براى سنجش استعداد به الكليسم وجود نداشت و همجنين فقط از خرده مقياس استعداد به الكليسم استفاده شد، استفاده از مقياس ضرورت داشت. خرده مقياس MAC.R (استعداد به الكليسم): اين خرده مقياس توسط Mac Andrew دجار سوءمصرف الكل نيستند از افراد تحت درمان براى سوءمصرف الكل ساخته شده است. اين خرده مقياس شامل وq سؤال است. براى سنجش اعتبار يرسشنامه از آزمون كودر ريجاردسون استفاده شده است كه در اجراى مقدماتى، آلفاى به دست آمده براى مقياس به اين ترتيب شامل: VV| • بود (ه (1). يرسشنامه فراشناخت (Metacognitions Questionnaire-30): اين : يرسشنامه ·r ماده دارد و هر آزمودنى به مادهها به صورت جهار

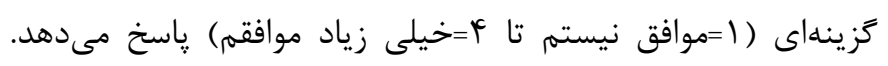
اين يرسشنامه، ينج مؤلفهى اعتماد شناختى، باورهاى مثبت در مورد

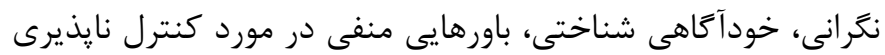
افكار و خطر و باورهايى در مورد نياز به كنترل افكار را مىسنجد. ضريب آلفاى كرونباخ اين يرسشنامه و مؤلفههاى آن در دامنهاى از

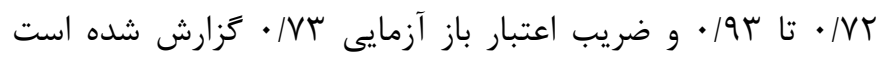

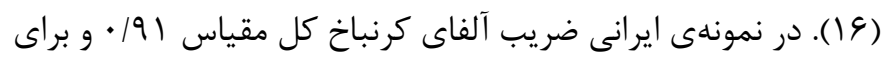
خرده مقياسهاى كنترل نايذيرى، باورهاى مثبت، آكاهى شناختى،

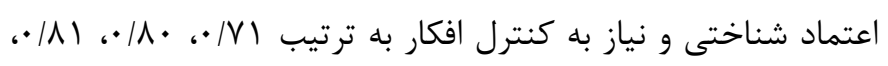

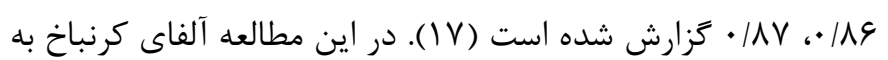
دست آمده فر آيند اجراى جلسات: روش درمان فراشناختى گروهى بر اساس الخوى فراشناختى Wells مبتنى بر نقايص فراشناختى به صورت گروهى و در ^ جلسه دو ساعته به شرح زير صورت گرفت (1) ).
استعداد به الكليسم است. با توجه به كمبود و شكاف ميان يزوهش هاى صورت گرفته در اين زمينه، در اين يزوهش تلاش شده تا نشان داده شود كه آيا درمان فراشناختى به كاهش استعداد به الكليسم در جوانان

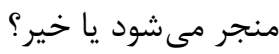

\section{روش كار}

يزوهش حاضر نيمه آزمايشى با طرح پِيش آزمون_يس آزمون با گروه كنترل و دوره پييخيرى بود. جامعه آمارى اين يزوهش شامل كليه دانشجويان مشغول به تحصيل مقطع كارشناسى به تعداد 11.FF نفر در سال تحصيلى و9-هوץ| دانشگاه فردوسى مشهد بود. در اين يزوهش از روش نمونه

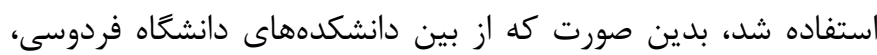
يك دانشكده و از بين كلاسهاى آن دانشكده ب كلاس انتخاب شدند

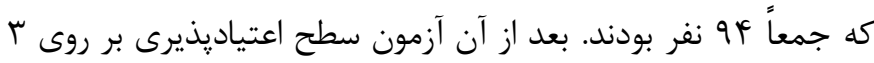

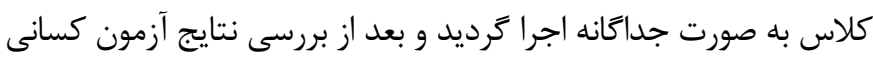

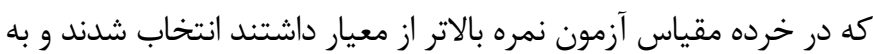
صورت تصادفى در گروه آزمايش و كنترل گمارده شدند (هر گروه ها انفر).

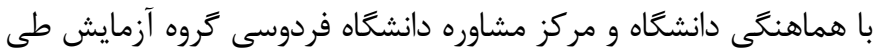
^ جلسه دو ساعته در يكى از كلاسهاى دانشكده تحت آموزش درمان فراشناختى قرار گرفتند. بعد از پايان جلسات، آزمون استعداد به الكليسم براى هر (Mac Andrew Alcoholism Scale-Revised (MAC.T̄)) دو گروه آزمايش و كنترل به صورت هم زمان انجام شد. ملاكهاى ورود

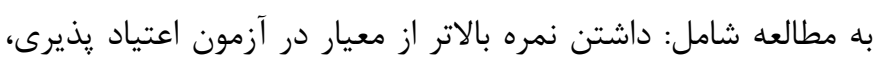
سن 11 تا F T سال، تحصيلات كارشناسى، داراى آكاهى و شناخت لازم براى درك جلسات درمانى و انجام تكاليف و ملاكهاى خروج شامل داشتن همزمان ساير بيمارىهاى مزمن و اختلالات روانى، تحت درمان روانشناختى ديگر بودن، سوءمصرف مواد و استفاده از دارو بود. از كليه مشاركتكنندكان در يزوهش رضايتنامه كتبى دريافت شد و به آنان اطمينان داده شد كه اختيار ادامه مشاركت در طرح درمان را دارند. همجنين به آنان اطمينان داده شد كه هويت

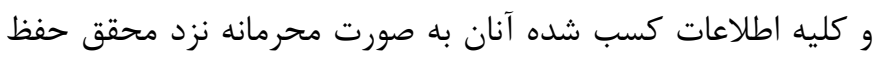
خواهد شد. در اين يزوهش از مقياس آمادگى به اعتياد و يرسشنامه فراشناختى استفاده شد.

يرسشنامه اعتياديذيرى (Addiction Potential Scale): اين يرسشنامه از يرسشنامه شخصيتى جندوجهى مينه سوتا (MMPI) ستخراج شده است. اين : رسشنامه شامل •9 سؤال است كه در آن آزمودنى پاسخ خود را به صورت بله و خير معين مى كند، سيس 


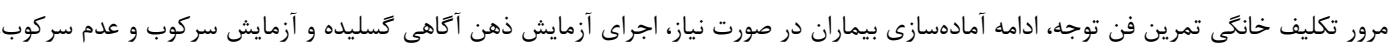

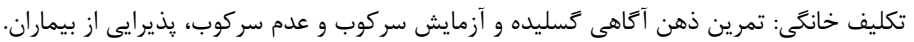

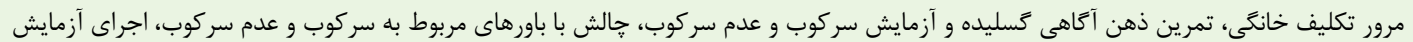

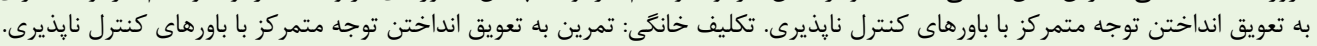

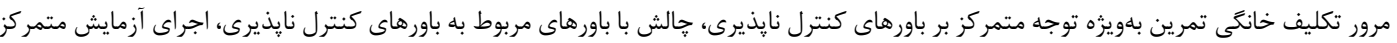



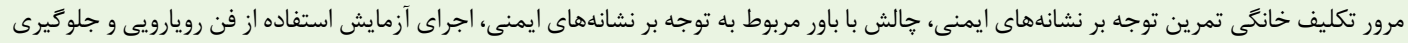

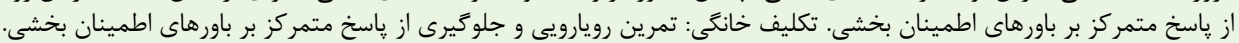

ينجمم

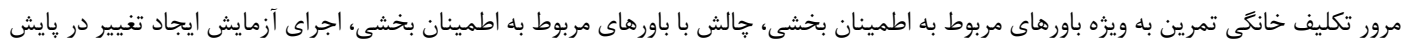

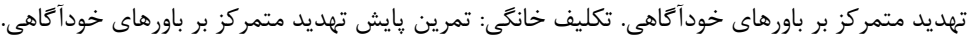

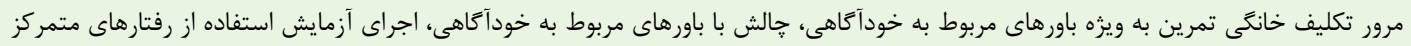

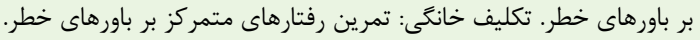

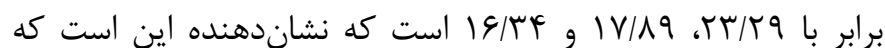

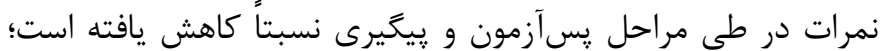
بنابراين نتايج حاكى از تفاوت ميانكين نمرات استعداد به الكليسم در بران هر مرحله دارد. در حالى كه ميانگين همين مقياس در گروه كنترل در

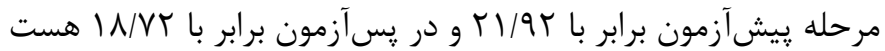
كه تفاوت محسوسى بين دو گروه آزمايش و كواه اتفاق افتاده است. ييش فرضهاى آزمون تحليل كوواريانس (ANCOVA)

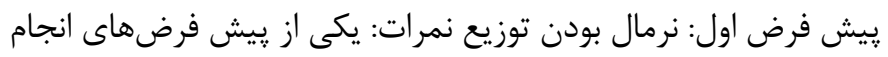

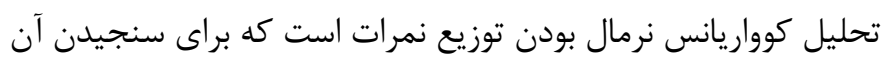

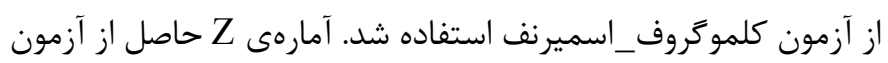

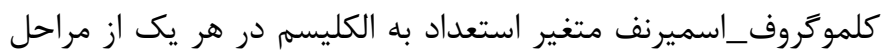

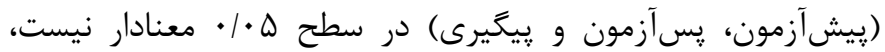
بنابراين فرضيه صفر يعنى پيروى داده از توزيع نرمال تائيد مىشود. קيش فرض دوم: همَنى رگرسيون: يكى ديكر از بيش فرضهاى اجراى تحليل كوواريانس، همكنى ضرايب ركرسيون است. كه خطوط رَرسيون
تحليل دادهها، در دو بخش آمار توصيفى و آمار استنباطى انجام شد. از

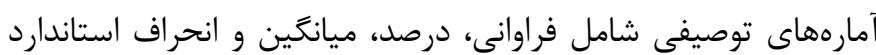
براى توصيف مشخصات جمعيت شناختى و متغيرهاى يزوهش استفاده شد. در بخش آمار استنباطى نيز از آزمون t زوجى و تحليل كوواريانس براى به آزمون كذاشتن فرضيههاى يزوهش در سطح

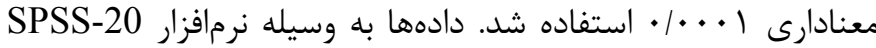
تجزيه و تحليل شد.

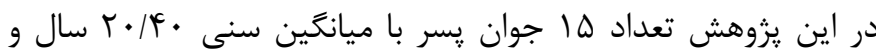

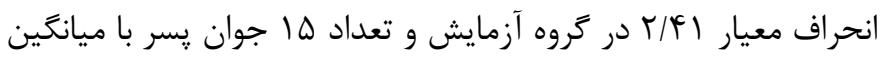

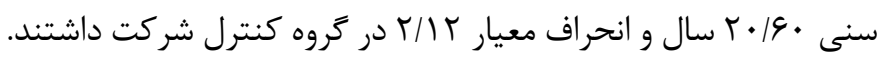
در جدول r ميانكين و انحراف معيار خرده مقياس استعداد به الكليسم

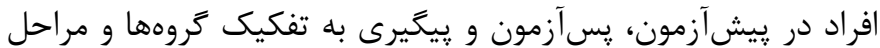
كزارش شده است. نتايج جدول r نشان مىدهد كه ميانگين استعداد به الكليسم گروه آزمايش در هر يك از مراحل بيشآزمون، پِسآزمون و پييخيرى به ترتيب 
جدول r. ميانگين و انحراف معيار نمرات خرده مقياس استعداد به الكليسم افراد در پِيشآزمون، بِ آزمون و بِيخيرى

\begin{tabular}{|c|c|c|c|c|}
\hline تعداد & 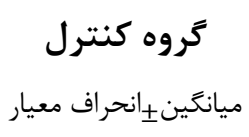 & 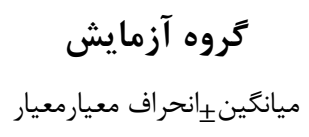 & مر احل & متغير ها \\
\hline 10 & T/rTI & $r / घ q \pm r r / r q$ & 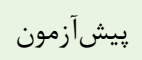 & \\
\hline 10 & $r / \wedge 9 \pm 1 \wedge / V r$ & $r / r r \pm I V / \wedge q$ & يس آزمون & استعداد به الكليسم \\
\hline 10 & $1 / 09 \pm 19 / 4 q$ & $r / T r \pm \mid \varepsilon / \mu r$ & بيخيرى & \\
\hline
\end{tabular}

اجراى تحليل كوواريانس بايد رعايت شود همخنى واريانسها است كه به وسيله آزمون لوين بررسى مىشود. نتايج همخنى واريانسها

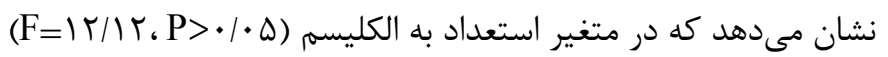

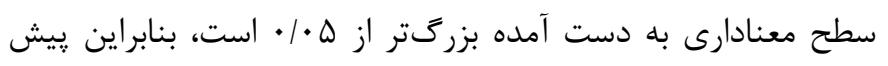
فرض همگنى واريانسها در هر دو متغير يروهش رعايت شده است. با توجه به اينكه هر جهار ييش فرض انجام تحليل كوواريانس تائيد شدند، در ادامه از تحليل كوواريانس استفاده شد. جهت تعيين اثربخشى فراشناخت درمانى در كاهش استعداد به الكليسم دانشجويان از آزمون تحليل كوواريانس براى مقايسه نمرات ييشآزمون، پِآزمون بين دو

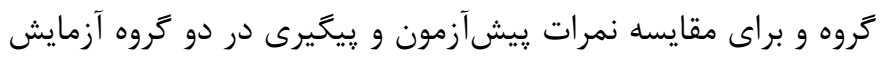
از آزمون T همبسته استفاده شده است. فرضيه: مداخله فراشناخت درمانى استعداد به الكليسم را كاهش مى آدهد. نتايج جدول تحليل كوواريانس نمرات يسآزمون استعداد به الكليسم نشان مى دهد كه يس از تعديل نمرات ييشآزمون، اثر معنادار عامل بين آزمودنى هاى وجود داشت. نمرات ميانگين تعديلشده آمادگى به اعتياد بيشنههاد مى كند، گروهى كه در گروهدرمانى فراشناختى شركت كردند در مقايسه با گروه گواه كه تحت هيج درمانى قرار نخرفتند، داراى استعداد به
هر دو گروه موازى باشد. نتايج آزمون همگنى ضرايب رگرسيون مفروضه

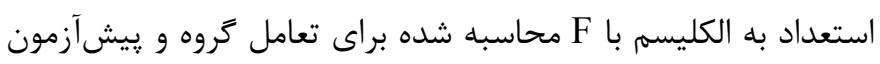

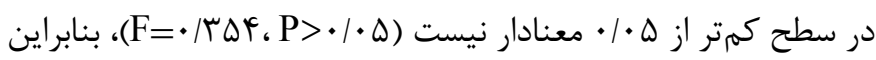

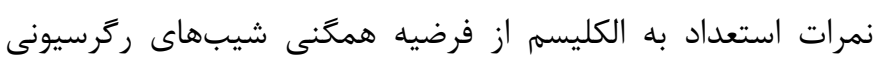
حمايت مى كنند و اين بيشفرض رعايت شده است. ييش فرض سوم: خطى بودن: در اين مرحله نمودار يراكنش متغيرها به تفكيك گروهها مورد بررسى قرار مى گيرد تا مشخص شود آيا بين متغير تصادفى كمكى و متغير وابسته ارتباط خطى وجود دارد؟ اگر رابطه خطى وجود نداشت دليلى براى اجراى تحليل كوواريانس وجود ندارد اما اتر نوعى رابطه خطى بين آنها وجود داشته باشد يا به عبارت ديخر شيبهاى خطوط ركرسيون تقريباً موازى باشند يعنى ارتباط بين متغير تصادفى كمكى و متغير وابسته در هر دو گروه شبيه باشد (مفروضه همگنى رگرسيونها) مىتوان از تحليل كوواريانس استفاده كرد. مقدار مجذور R نشاندهنده درجه و شدت ارتباط بين متغير وابسته و متغير تصادفى كمكى است. آزمون بررسى همگنى شيب ركرسيون نيز نشان داد كه تعامل متغيرها معنادار نيست. اثر ريلايى شيب ركرسيون نيز ( F= ( نشان مى دهد كه فرض همخنى رگرسيون برقرار است. ״يش فرض جهارم: همگنى واريانسها: مفروضه ديگرى كه براى

جدول r. نتايج تحليل كوواريانس نمرات يِآزمون متغير استعداد به الكليسم

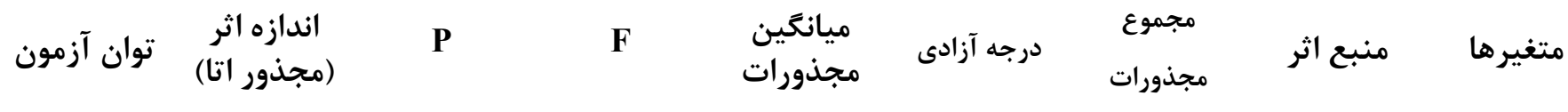

\begin{tabular}{|c|c|c|c|c|c|c|c|c|}
\hline 1 & $\cdot / F \Delta$ &.$/ . .1$ & $119 / \cdot V$ & rוTIRT & 1 & TIKI/FT & پيش آزمون & استعداد له \\
\hline 1 & $\cdot / V T$ & $\cdot / \cdot \cdot 1$ & NT/GY & $9 \Delta \cdot / \pi T$ & 1 & $9 \Delta \cdot / r T$ & كروه & الكليسم \\
\hline
\end{tabular}


داد كه درمان فراشناختى در كاهش استعداد به الكليسم دانشجويان

الكليسم يايينترى بودند و ميزان تأثير كذارى آن VT درصد است؛ يعنى

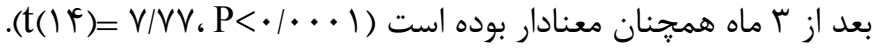

فراشناخت درمانى بر روى كروه آزمايش به ميزان VT درصد توانسته

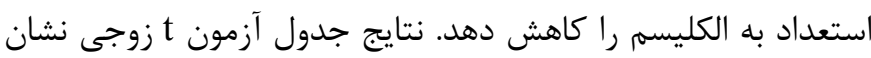

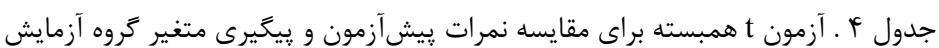
$\mathbf{P}$
درجه آزادى
$\mathbf{t}$
ميانگين土انحراف معيار
متغير
$\cdot 1 \cdot \cdot 1$
If
V/VV
$T / T T \pm \Delta / \Delta S$
استعداد به الكليسم (MAC.R) - (2)
(MAC.R)

تبيينهاى رفتارى، زنتيك و شناختى استفاده كردهاند. ولى اين ديدگاه محدوديتهايى دارد و باورهاى فراشناختى را ناديده مى گيرد. در اين קارجوب بايد گفت يكى از مههترين متغيرهاى پيشبين اختلال سوءمصرف مواد، فراشناخت است كه شامل باورهاى فرد در مورد افكارش است. برخى از يزوهشها، فراشناخت را به عنوان ميانجى رابطهى بين

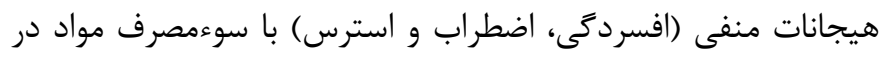

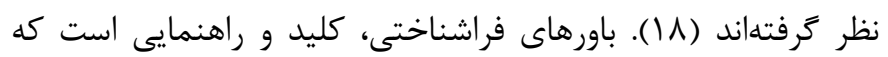

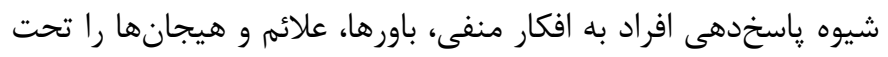

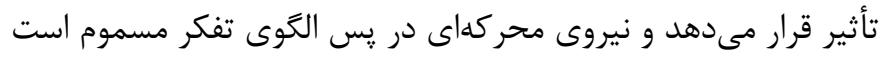

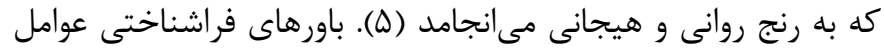

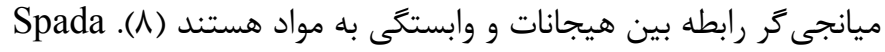

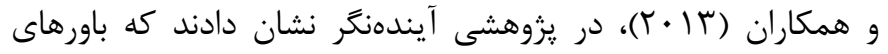
فراشناختى و هيجانات منفى عامل خطرى براى مصرف الكل و ميزان

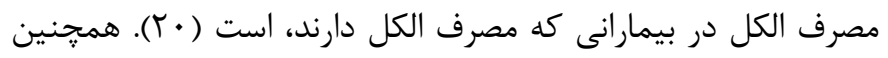
Caselli

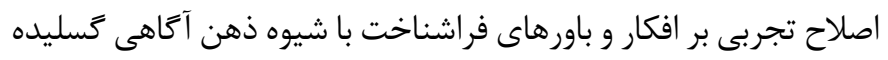

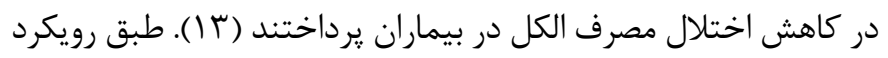

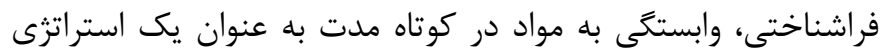
مقابلهاى سازكارانه براى تنظيم هيجانات منفى عمل مى كند ولى در بلند مدت ناسازكارانه محسوب مىشود، زيرا باعث ايجاد وابستگى و

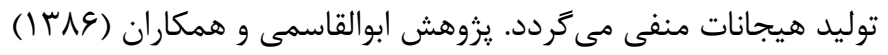

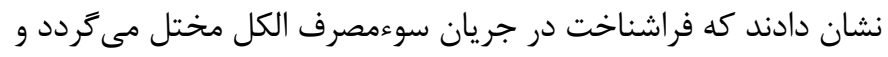



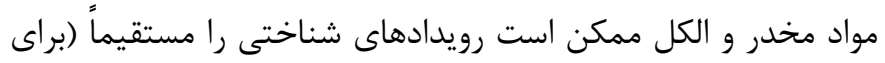

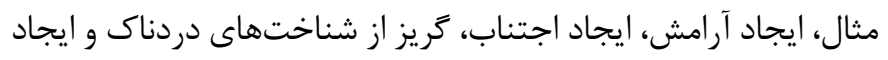

اين يزوهش باهدف بررسى اثربخشى درمان فراشناختى بر كاهش استعدادبه الكليسم دانشجويان كارشناسى دانشگاه فردوسى انجام گرفت. نتايج تحليل كوواريانس نمرات پِّآزمون استعداد به الكليسم نشان داد كه پِ إز تعديل

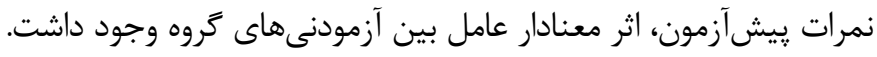

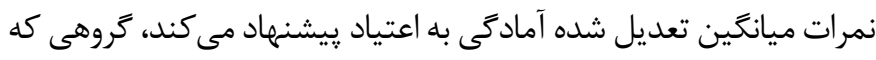

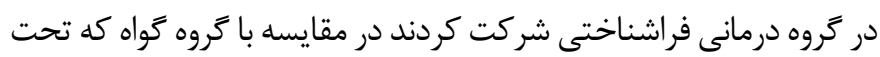

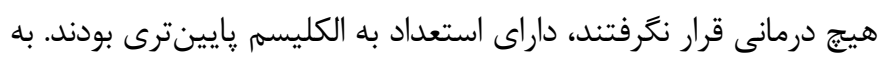

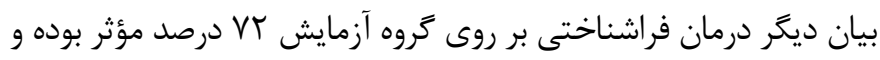
توانسته است استعداد به الكليسم گروه هدف را كاهش دهد. بنابراين فرضيه يزوهش تائيد مىشود. اين يافته تحقيق حاضر با ساير يافتههاى تحقيقات

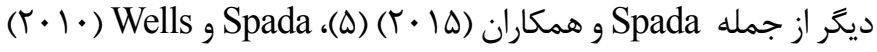

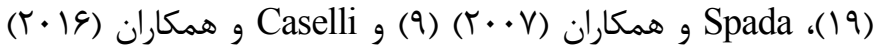

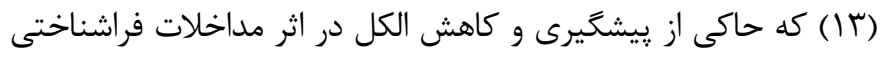

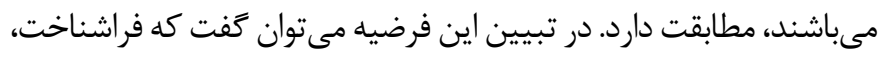

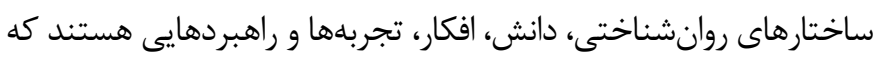

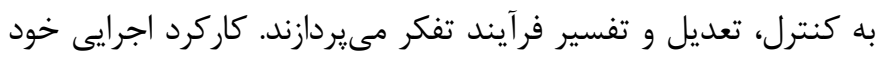

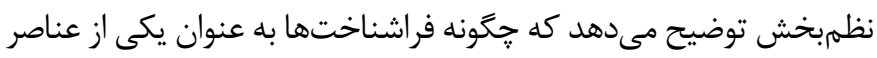
يردازش دادهها باعث آغاز و تداوم مشكلات روانشناختى مىشوند، در اين مدل فرض بر اين است كه در اختلالات روانى، باورها و دانشهايى كه داراى

ماهيت فراشناختى هستند، نحومى تفكر و راهبردهاى مقابلهاى فرد را

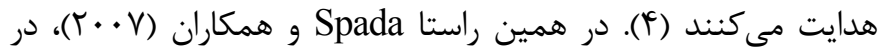
يزوهشى به مدل ميانجى تعديل كننده فراشناختها در رابطه بين هيجانات

و وابستخى الكل در بين دانشجويان دانشعاه دست يافت (9).

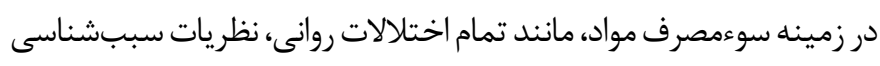
اوليه از مدلهاى روانيويشى مايه ترفتهاند و مدلهاى بعد از 
تمركز و توجه معتادان داشته باشد و همجنين تأثير فن آموزش توجه

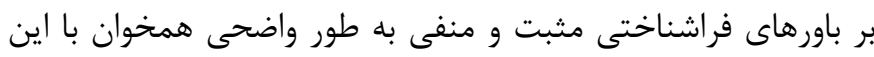

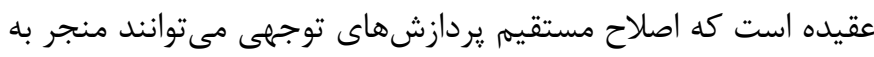

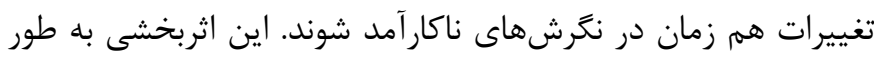

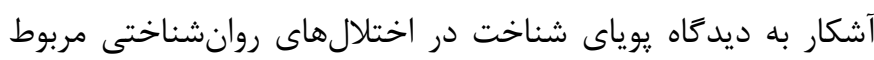

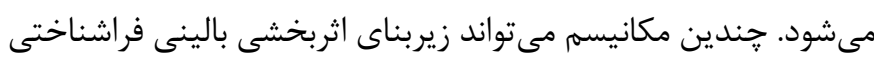

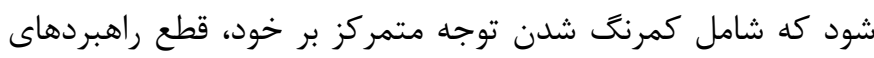

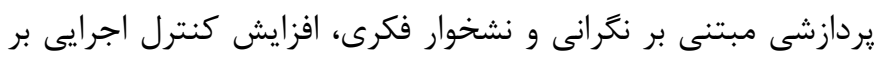
يردازش و توجه و تقويت شيوهى يردازش فراشناختى هستند. از جمله محدوديتهاى يزوهش حاضر، مى توان به عدم توجه به متغير جنسيت

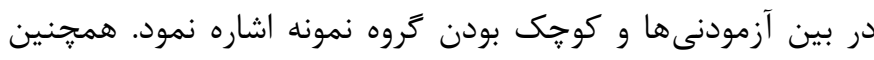

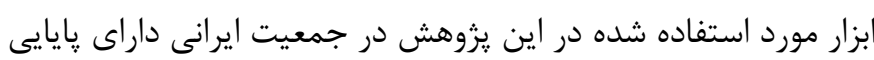

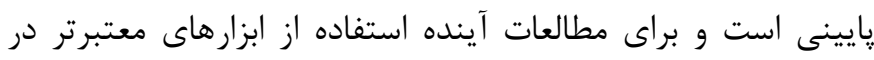

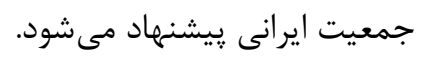

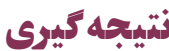

به طور كلى نتايج اين يزوهش حاكى از آن بود كه درمان فراشناختى،

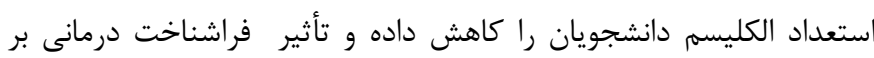
ميزان استعداد الكليسم دانشجويان در مرحله پِيخيرى بعد از ب ماه همجنان

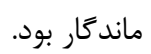

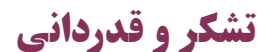

در پِايان از كليه دوستان و همكاران عزيز كه ما را در انجام اين يزوهش

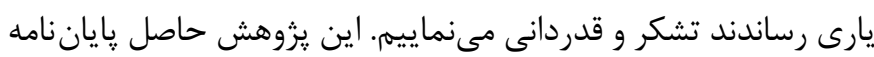

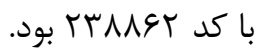

\section{References}

1. Sadock BJ, Sadock VA, Ruiz P. Kaplan \& Sadock's synopsis of psychiatry : Behavioral sciences/clinical psychiatry. 11th ed. New York:Wolters Kluwer;2015.

2. Askari S, Zakiyi A, Alikhani M. The relationship between personality characteristics (neuroticism, psychoticism and extraversion) and site avoidance for preparation of substance abuse among male students. Journal of Psychological Sciences. 2012;10(40):485-497.

3. Normann N, Van Emmerik AA, Morina N. The efficacy of
آكاهى و توجه) و يا بهطور غيرمستقيم (براى مثال، احساس دلبستخى، بهتزدكى و ارزيابىهاى سركوبشده) با تغيير باورها و نكرشها در

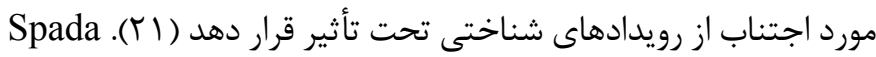

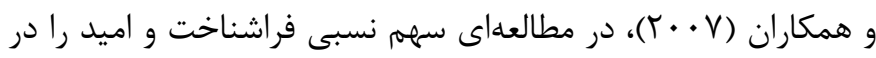

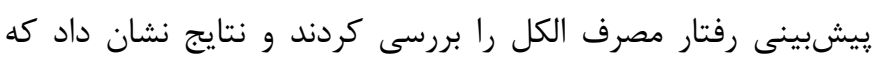

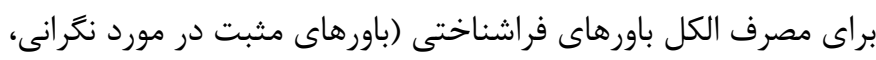
باورهاى منفى در مورد افكار مربوط به خطر و كنترل نايذيرى، اعتماد شناختى و باور در مورد نياز به كنترل افكار) و كنترل توجه (تمركز، دونا تغيير و انعطاف كنترل افكار) نقش تعديل كننده دارند (9). همجنين Spada بالينى باورهاى فراشناختى مثبت و منفى در مورد استفاده از الكل،

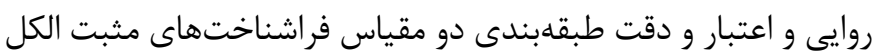
و (The Positive Alcohol Metacognitions Scale)

فراشناختهاى منفى الكل مe Negative Alcohol) (Metacognitions Scale

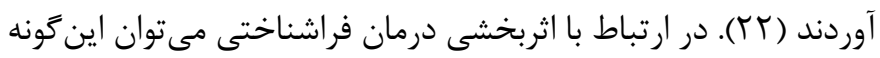

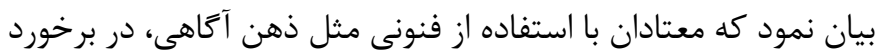
با فكرها و احساسهاى منفى و نكران ساز به جاى خالش با محتواى شناختها، روش غير قضاوتى بودن را با كمك تصويرسازى ذهنى آموزش مىبينند و با كسيختن نشخوارهاى ذهنى و كاهش تمايلات خود نظارتى غير سودمند، سبكهاى سازكارانه تر تفكر را را ايجاد

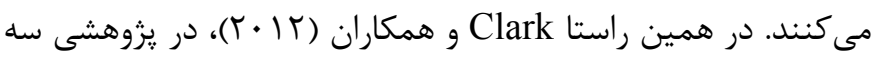

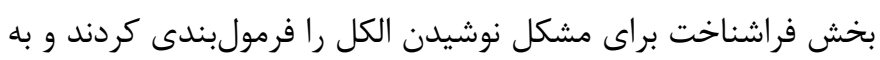

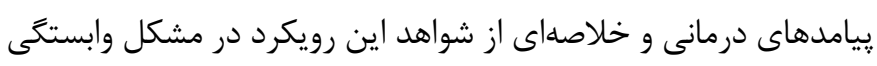

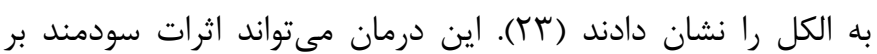

metacognitive therapy for anxiety and depression: A meta-analytic review. Depress Anxiety. 2014;31(5):402-411.

4. Capobianco L, Wells A. Letter to the editor: Metacognitive therapy or metacognitive training: What's in a name? Journal of Behavior Therapy and Experimental Psychiatry. 2018;59:161.

5. Spada MM, Caselli G, Nikčević AV, Wells A. Metacognition in addictive behaviors. Addictive Behaviors. 2015;44:9-15.

6. Sellers R, Varese F, Wells A, Morrison AP. A meta-analysis 
of metacognitive beliefs as implicated in the self-regulatory executive function model in clinical psychosis. Schizophrenia Research. 2017;179:75-84.

7. Papageorgiou C. Metacognitive Theory, therapy and techniques: Introduction to the special Issue. Cognitive Therapy and Research. 2015;39(1):1-3.

8. Fergus TA, Bardeen JR. The Attention Training Technique: A review of a neurobehavioral therapy for emotional disorders. Cognitive and Behavioral Practice. 2016;23(4):502-516.

9. Spada MM, Moneta GB, Wells A. The relative contribution of metacognitive beliefs and expectancies to drinking behaviour. Alcohol \& Alcoholism. 2007;42(6):567-574.

10. Toneatto T. A metacognitive analysis of craving: Implications for treatment. Journal of Clinical Psychology. 1999;55(5):527-537.

11. Verdejo-García A, Bechara A, Recknor EC, Pérez-García M. Negative emotion-driven impulsivity predicts substance dependence problems. Drug \& Alcohol Dependence. 2007;91(2):213-219.

12. Kavanagh DJ, May J, Andrade J. Tests of the elaborated intrusion theory of craving and desire: Features of alcohol craving during treatment for an alcohol disorder. British Journal of Clinical Psychology. 2009;48(3):241-254.

13. Caselli G, Gemelli A, Spada MM, Wells A. Experimental modification of perspective on thoughts and metacognitive beliefs in alcohol use disorder. Psychiatry Research. 2016;244:57-61.

14. Kordmirza E, Azad H, Eskandari H. Normalization of addiction potential scale for spotting individuals exposed to drug abuse among students of Tehran universities. Journal of Re- search on Addiction. 2003;1(2):47-80. (Persian)

15. Craig RJ. Assessing contemporary substance abusers with the MMPI MAC Andrews Alcoholism Scale: a review. Substance use \& misuse. 2005 Jan 1;40(4):427-50.

16. Wells A, Cartwright-Hatton S. A short form of the metacognitions questionnaire: properties of the MCQ-30. Behaviour research and therapy. 2004;42(4):385-396.

17. Shirinzadeh DS, Goodarzi MA, Ghanizadeh A, Naghavi MR. Investigating the factor structure, validity and reliability of the Meta-Cognition Questionnaire-30. Journal of Psychology. 2008;12(4):445-461. (Persian)

18. Wells A. Metacognitive therapy for anxiety and depression. New York:Guilford Press;2011.

19. Spada MM, Wells A. Metacognitions across the continuum of drinking behaviour. Personality and Individual Differences. 2010;49(5):425-429.

20. Spada MM, Caselli G, Wells A. A triphasic metacognitive formulation of problem drinking. Clinical Psychology \& Psychotherapy. 2013;20(6):494-500.

21. Aboulghasemi A, Ahmadi M, Kiamarsi A. The relationship of metacognition and perfectionism with psychological consequences in the addicts. Journal of Research in Behavioural Sciences. 2007;5(2):73-79. (Persian)

22. Spada MM, Wells A. Metacognitive beliefs about alcohol use: Development and validation of two self-report scales. Addictive Behaviors. 2008;33(4):515-527.

23. Clark A, Tran C, Weiss A, Caselli G, Nikčević AV, Spada MM. Personality and alcohol metacognitions as predictors of weekly levels of alcohol use in binge drinking university students. Addictive Behaviors. 2012;37(4):537-540. 